\title{
Becsült talajhidrológiai paraméterek szimulációs vizsgálata a NAIK Erdészeti Tudományos Intézet két mintaterületén
}

\author{
$1 *$ KozMA Zsolt, ${ }^{1}$ DeCsi Bence, ${ }^{2}$ MANNINGER Miklós, ${ }^{2}$ MóRICZ Norbert, \\ ${ }^{3,4}$ MAKó András, ${ }^{3,4}$ SzABÓ Brigitta \\ ${ }^{1}$ BME Vízi Közmü és Környezetmérnöki Tanszék, Budapest, \\ ${ }^{2}$ NAIK Erdészeti Tudományos Intézet, Sárvár, \\ ${ }^{3}$ MTA ATK Talajtani és Agrokémiai Intézet, Budapest, \\ ${ }^{4}$ PE Georgikon Kar, Keszthely \\ (Beérkezett: 2019.01.31.; Elfogadva: 2019.05.20.)
}

\section{Bevezetés}

A folyamatalapú hidrológiai számításoknak és az azokra épülő erdészeti, vízminőségi, ökológiai elemzéseknek jelentős és szerteágazó a bemenő adatigénye (GRIBOVSZKI et al., 2006, FARKAS et al., 2011, ARNOLD et al. 2012, FODOR et al. 2014, TRODAHL et al. 2017). A szimulációk alapját adó elméleti háttér, a számítási kapacitás és a térinformatikailag/numerikusan kezelhető térbeli felbontás folyamatos fejlődése miatt az adatigény további növekedése várható (VEREECKEN et al., 2016). A távérzékelés (KARIMI ÉS BASTIAANSSEN, 2015; MAHONTY et al., 2017) és az automata hidrometeorológiai monitoring rohamos fejlődésével (DORIGO et al., 2012; MóRICZ et al., 2012,, FIALA et al., 2014, Qu et al., 2016, GANOT et al., 2017) a hidrológiai modellek paraméterezése során az egyik legkomolyabb kihívást lokális és vízgyüjtő léptéken is a felszín alatti viszonyok, és elsősorban a telítetlen talajok szivárgáshidraulikai tulajdonságainak számszerüsítése jelenti (PRÁVETZ et al., 2015; VEREECKEN et al., 2016). A talajhidrológiai tulajdonságok meghatározása költséges, munka és időigényes, ezért azokat legtöbbször könnyen hozzáférhető talajtulajdonságok alapján határozzák meg, ún. pedotranszfer függvényekkel (PTF). Legtöbbször PTF-ekkel számítják a talaj víztartó- és vízvezető képességét jellemző paramétereket (VAN LOOY et al., 2017) is. A közelmúltban más módszertannal (matematikai háttér, alapadatok, térbeliség, leírt talajtulajdonságok) több hazai és nemzetközi talajhidrológiai adatbázist is kidolgoztak (BAKACSI et al., 2012; DAI et al., 2013; MARTHEWs et al., 2014; CHANEY et al., 2016; MONTZKA et al., 2017; TóTH et al., 2017; Wu et al., 2018).

A környezeti modellezés támogatására létrehozott talajhidrológiai adatforrások megbízhatóságát viszonylag ritkán vizsgálják egymással és mérésekkel összehasonlítva, kifejezetten hidrológiai, vagy vízminőségi, stb. szempontokból. Ez elsősorban a modellezett környezeti jellemzők mérésének a hiányával magyarázható. Ezért legtöbbször arra van csak lehetőség, hogy a modellel számított talajhidrológiai paraméterek modell alkalmazásbeli hatását vizsgálják, és így az adatforrásokat egymással hasonlítsák össze (VEREECKEN et al., 1992; NEMES et al., 2003; ZHAO et al., 2018). Egy-egy alkalmazásban a modellben használt

*Levelezö szerzö: KozMA ZsOLT, BME Vízi Közmü és Környezetmérnöki Tanszék, 1111 Budapest, Mủegyetem rkp. 3

E-mail: kozma.zsolt@epito.bme.hu 
paraméterek közvetett és/vagy egyedi értékelésére van példa (pl. SCANLON et al., 2002, KOZMA et al., 2014, GANOT et al., 2017).

GANOT et al. (2017) indirekt módon, egy mesterséges víztározó talajvízszintre gyakorolt hatásának vízforgalmi modellezésével (Hydrus-1D) mutatták ki az európai pedotranszfer függvények (EU-PTF-ek) (TóTH et al., 2015) megbízhatóságát A talajrétegek hidrofizikai tulajdonságait több elterjedt adatforrás alapján határozták meg. Ezek közül az EU-PTF-ekkel számított talajhidrológiai paraméterekkel kapták a talajvízszint-változásokat legpontosabban leíró szimulációs eredményeket. SCANLON et al. (2002) összehasonlító vizsgálatukban bizonyították, hogy a helyszíni talajnedvesség mérésekkel is összehasonlított vízforgalmi modellszámítások értékes információkat szolgáltatnak a matematikai leírás, a szimulációs algoritmusok és a felhasznált adatok bizonytalanságáról is.

A fenti vizsgálatok mintájára általunk elvégzett elemzéseket alkalmasnak tartjuk a bemenő talajparaméterek adatbázisainak értékelésére. Ezért kutatásunkban azt vizsgáljuk, hogy a jelenleg fejlesztés alatt álló, a Balaton vízgyűjtőjére kiterjedő 3D talajhidrológiai adatbázis (i) mennyire megbízható adatforrás, és (ii) a már elérhető talajhidrológiai adatbázisokhoz képest vajon javítja-e a talajszelvény léptékủ vízforgalmi modell számítások pontosságát

\section{Vizsgálati anyag és módszer}

Az elemzés az alábbi gondolatmeneten alapult:

(1) Egy-egy monitorozott talajszelvény időben változó nedvességviszonyait a talajhidrológiai szempontból különbözőképp paraméterezett (talajrétegek vastagsága, víztartó- és vízvezető képesség Mualem-van Genuchten-féle paraméterei, VAN GENUCHTEN, 1980), de minden más szempontból azonosan felépített szivárgáshidraulikai modellváltozatok várhatóan eltérő eredményességgel írják le;

(2) Ezért ha az egyéb felhasznált adatok (elsősorban a talajnedvesség-mérések és a meteorológiai peremfeltételek) kellően pontosak, akkor feltételezhetjük, hogy az egyes modellváltozatok jósága az azokhoz felhasznált talajhidrológiai paraméterek hidrológiai szempontú megbízhatóságától függ.

(3) $\mathrm{Az}$ (1)-(2) elemzés a talajhidrológiai bemeneti információkat biztosító adatbázisok pontszerü összehasonlító értékelésének tekinthető, amit minél több pontra végzünk el, annál átfogóbb képet kapunk az adatbázisok megbízhatóságáról.

A kétéves kutatásban öt, a Balaton vízgyüjtőjén található mérési pont feldolgozása zajlik, közülük elemzésünkben két talajszelvény modellezési eredményeit mutatjuk be. A szimulációkat Hydrus-1D szoftverrel végeztük. A számítások bemeneti adataiként és az eredmények értékeléséhez két erdészeti monitoring állomás hidrometeorológiai és talajnedvesség idősorait használtuk fel. 


\section{Mintaterületek}

A két vizsgált helyszínen, Fiadon és Szalafőn az Erdészeti Tudományos Intézet (NAIK ERTI) folytat hidrometeorológiai monitoring programot. A fiadi helyszín az Erdészeti Mérő- és Megfigyelő Rendszer (EMMRE) részeként müködő klímamonitoring egyik mérőhelye. A klímamonitoring hálózat kiépítésének egyik célja a klimatikus változások helyi sajátosságainak megismerése az egyes erdőterületeken végzett meteorológiai és talajnedvesség-mérések adatai alapján. Fiadon a talajnedvesség mérések - 10, 20, 30, 50 és $100 \mathrm{~cm}$ mélységben -15 perces felbontásúak. A vizsgálatokban a 2016.03.08-2017.10.26. időszak átlagos napi adatait vettük figyelembe. Minthogy helyben mért meteorológiai adat nem áll rendelkezésre, ezért a csapadék esetében a Dél-Dunántúli Vízügyi Igazgatóság által Gamás-Vadépusztán (Fiadtól 3,6 km) üzemeltetett mérőállomás adataival dolgoztunk, míg a többi meteorológiai jellemző esetében a NAIK ERTI karádi (Fiadtól 9,3 km) méréseire támaszkodtunk. A vizsgált két évben a sokévi átlagoshoz (725 mm/év) képest több csapadék hullott (765, ill. $823 \mathrm{~mm} / \mathrm{év}), 71 \mathrm{~mm}$-es maximális napi csapadékösszeggel. A terület meteorológiai szempontból a vízgyüjtőn belül átlagos. A szelvény erdő területen van (erdőmüvelés a vízgyüjtő 27\%-án zajlik).

A szalafői helyszín az EMMRE részeként müködő intenzív monitoring egyik szabadterületi mérőhelye. Az intenzív monitoring célja az erdők egészségi állapotának jellemzése és változásának nyomon követése, az erdei ökoszisztémákban zajló folyamatok (víz- és szervesanyag-forgalom, stb.) feltárása, az ok-okozati összefüggések megismerése. A szabadterületi meteorológiai mérések (köztük kiemelten a csapadékmérések) az állomány alatti mérésekhez szolgálnak viszonyítási alapként. Szalafơn 10 perces mérési adatokból aggregált napi felbontású meteorológiai és talajnedvesség idősorok - 5-10, 20, $40 \mathrm{~cm}$ mélységben - állnak rendelkezésre. Jelen cikkben a 2013.01.01-2014.12.31 időszak adatait használtuk a modellezéshez. Szalafő a vízgyüjtő leginkább csapadékos részén található, a vizsgált időszakban pedig a sokéves átlaghoz ( $825 \mathrm{~mm} / \mathrm{e} v)$ képest is több hullott (851, ill. $958 \mathrm{~mm} / \mathrm{év})$. A vizsgált terület gyep múvelésü (gyepgazdálkodás a vízgyüjtő 12\%-án történik). A talaj nedvességét Fiadon Decagon $\mathrm{ECH}_{2} \mathrm{O}$ EC-5 (Decagon Devices, Pullman, USA) szenzorokkal, Szalafőn Campbell CS616 reflektométer szondákkal mértük. Mindkét esetben a gyári kalibrációt használtuk.

A kutatás részeként mindkét helyszínen végeztünk talajszelvény-feltárást, mintavételt, és meghatároztuk a talaj legfontosabb kémiai, fizikai és vízgazdálkodási tulajdonságait. A talaj fizikai tulajdonságait és víztartó képességét az MSZ-08-0205-78 szerint mértük, a kémiai jellemzőket és a hidraulikus vezetőképességet - csökkenő víznyomásos módszerrel meghatározva - pedig BUZÁs (1988, 1993) alapján.

\section{Vizforgalmi modellezés - elméleti háttér}

A talajszelvény szintű vízforgalmi számításokat a széles körben elterjedt Hydrus-1D szoftverrel (SIMUNEK et al., 1998) végeztük el. A szimulációkban azt vizsgáltuk, hogy a különbözőképpen származtatott és eltérő pontosságú 
talajhidrológiai paraméterek mennyiben befolyásolják a vízforgalmi számítások eredményeit. A talajszelvényekben lejátszódó telítetlen szivárgás fizikai alapú szimulációja az egydimenziós Richards-egyenlet numerikus megoldásával történt (SIMUNEK et al., 1998).

$$
\frac{\partial \theta(h)}{\partial t}=\frac{\partial}{\partial x}\left[k(h)\left(\frac{\partial h}{\partial x}+1\right)\right]-S(h)
$$

Az (1) háromváltozós parciális differenciálegyenlet megoldásához szükséges (i) az S(h) taggal jelölt növényi vízfelvétel ismerete/becslése és (ii) a telítetlen talajok víztartó- és vízvezető képesség görbéinek folytonos alakú leírása is. Az erre szolgáló talajfizikai függvények közül a (2)-(4) Mualem-van Genuchten modell az egyik legelterjedtebb (NIMMO, 2009). Ezt jelzi az is, hogy a talajhidrológiai adatbázisok a víztartó- és vízvezető képesség görbéket jellemzően a Mualem-van Genuchten-féle paraméterezéssel adják meg. Mi is ezt a függvényt használtuk ezért a talajszelvények vízgazdálkodási tulajdonságainak leírásához.

$$
\begin{gathered}
\theta(h)=\left\{\begin{aligned}
\theta_{r}+\frac{\theta_{s}-\theta_{r}}{\left[1+|\alpha \cdot h|^{n}\right]^{m}}, & h<0 \\
\theta_{S}, & h \geq 0
\end{aligned}\right. \\
k(h)=k_{s} \cdot S_{e}^{l}\left[1-\left(1-S_{e}^{\frac{l}{m}}\right)^{m}\right]^{2} \\
S_{e}=\frac{\theta-\theta_{r}}{\theta_{s}-\theta_{r}}
\end{gathered}
$$

Ahol $\theta(h)$ a talaj nedvességtartalma $\left(\mathrm{cm}^{3} / \mathrm{cm}^{3}\right) h$ nedvességpotenciál értéken $(\mathrm{cm}) ; \theta_{r}$ a maradó víztartalom $\left(\mathrm{cm}^{3} / \mathrm{cm}^{3}\right) ; \theta_{s}$ a telített víztartalom $\left(\mathrm{cm}^{3} / \mathrm{cm}^{3}\right) ; \alpha$ $(1 / \mathrm{cm})$ a levegő belépési pont nyomásérték inverze, $n, m$ és $l$ (-)illesztési paraméterek; $k(h)$ a vízvezető képesség $h$ nedvességpotenciál értéken ( $\mathrm{cm} / \mathrm{nap}) ; k_{s}$ a telített állapothoz tartozó vízvezető-képesség (cm/nap); $S_{e}$ az effektív telítettség.

Az 1D Richards-egyenlet megoldása csak a telítetlen talajban zajló szivárgás mélység- és időbeli leírását biztosítja. A környezeti hatásoknak kitett talajszelvény vízforgalmának számításakor többnyire feltételezik a teljes talaj-növény-légkör (soil-vegetation-atmosphere, SVAT) rendszer kezelését (VEREECKEN et al., 2016). Ez a felszíni víz- és energiamérleget leíró összefüggések egyidejü megoldását, és további, a növényi vízfelvétel becslésére szolgáló vegetációs összefüggések és paraméterek bevonását jelenti. A vegetációhoz köthető csapadékfelfogás (intercepció), párologtatás (evapotranspiráció) és a gyökérzet vízfelvételét gátló vízstressz jelenségek leírására a Hydrus-1D program korlátozott, azaz döntően a mezőgazdasági haszonnövényekre szabott lehetőségeket biztosít (lásd még lentebb).

\section{Vízforgalmi modellezés - gyakorlati megvalósitás}

A modellváltozatok felépítése a két talajszelvény esetén számos ponton egyezett. A szelvényfeltárás és a nedvességmérések alapján kijelölt számítási tartományt (Fiad: $150 \mathrm{~cm}$; Szalafö: $110 \mathrm{~cm}$ ) azonosan $1 \mathrm{~cm}$-es lépésközü csomópontokkal osztottuk fel. A talajrétegek határait a talajhidrológiai adatok 
forrásától függően adtuk meg (lásd lentebb). A talajnedvesség-szenzorok helyét a modellben egy, illetve szükség esetén két megfigyelési ponttal vettük figyelembe. Erre azért volt szükség, mert a réteghatárok közelében elhelyezett szenzorok az általuk lefedett (változó talajtulajdonságú) tartomány nedvességviszonyait térben átlagolva mérik, viszont a Hydrus-1D egy-egy diszkrét megfigyelési pontban rögzíti az ott számolt víztartalmat. Tapasztalatunk szerint a megfigyelési pontok térbeli elhelyezése nagymértékben befolyásolta a mért és számolt nedvesség idősorok egyezését. A kezdeti feltételeket a mért nedvességtartalmak alapján állítottuk be. Mivel a talajvíz hatása egyik feltárt szelvénynél sem volt érzékelhető, alsó peremfeltételként szabad kifolyást (free drainage) állítottunk be. Az esésviszonyok miatt a felszíni lefolyást lehetővé tettuik. A napi bontású felső peremfeltételt (1. ábra) a légköri állapotok alapján számolt, intercepcióval csökkentett csapadék (léghőmérséklettől függően eső vagy hó) és potenciális evapotranszspiráció (PET) idősorok jelentették. Utóbbit a Penman-Monteith (MONTEITH, 1965) képlettel határoztuk meg.
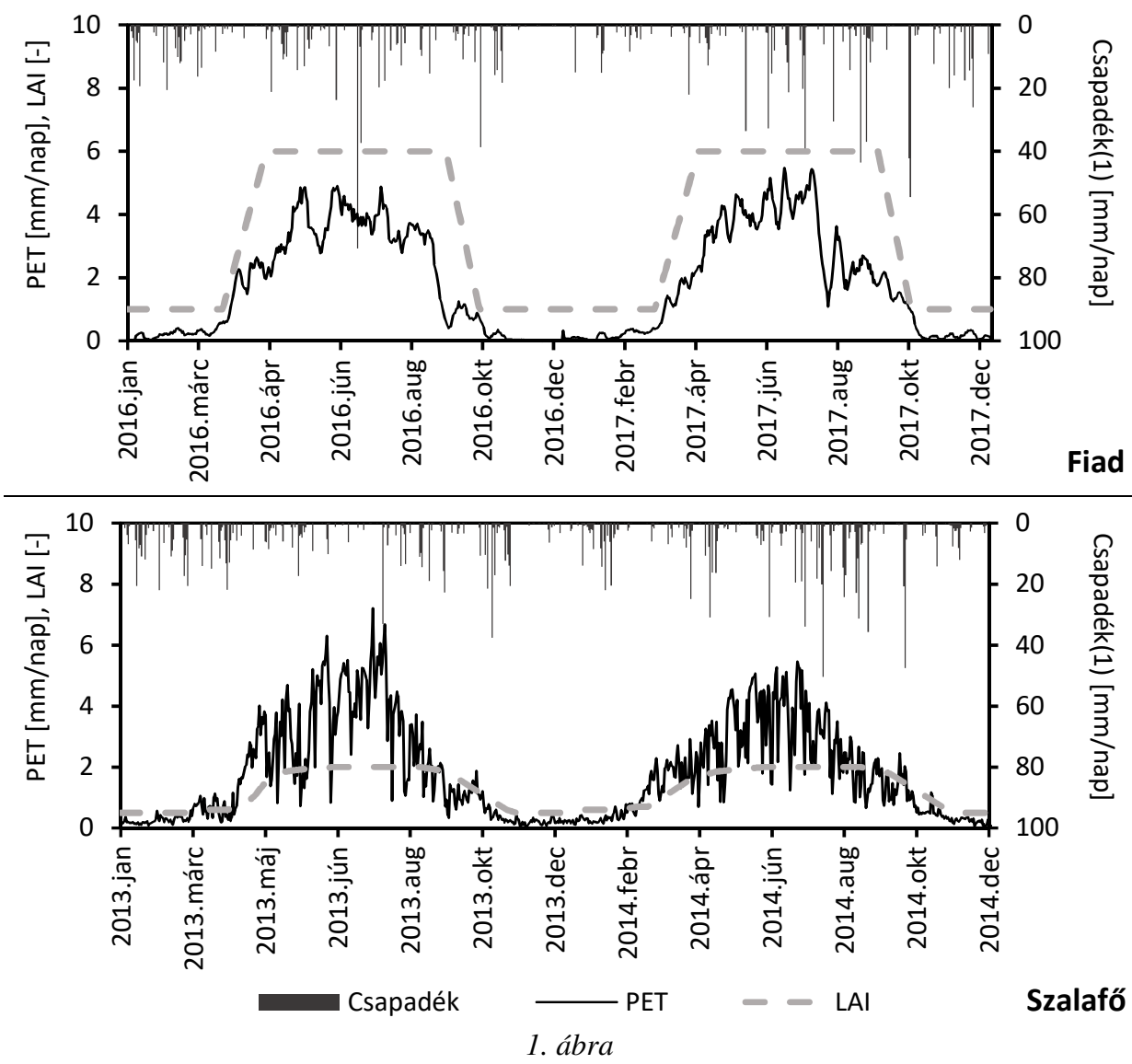

Csapadék, párolgás (PET), levélfelületi index (LAI) Fiad és Szalafő mérési helyeken 
A Hydrus-1D vegetációs modulját (intercepció és sugárzási elnyelődés, gyökérzet, vízfelvételi stresszfüggvény) döntően mezögazdasági növénykultúrák leírására fejlesztették ki. Ugyanakkor a kiterjedt lombkoronájú növényzet intercepciója jelentősebb és összetettebb. Mértékét számos meteorológiai és vegetációs tényező szabja meg, amelyeket a Hydrus-1D csak egyszerüsítésekkel, vagy közvetve vesz figyelembe. Ilyenek a csapadék intenzitása és halmazállapota, a szélsebesség, a páratartalom, illetve a lombkorona, a törzs és az avar felületarányának időbeli változása (KISS et al, 2005). Ezért a zárt faállományú Fiad mérőhely esetében a lombkoronához köthető vízmérleg elemeket (intercepció, potenciális és tényleges evapotranszspiráció) az erdészeti célokra alkalmasabb Brook90 modell (FEDERER, 2002) segítségével határoztuk meg. A Brook90 modellel számolt talajba beszivárgó csapadék és PET értékeket használtuk peremfeltételként a Hydrus-1D modellben. Ugyanakkor az algoritmus talajhidrológiai modellként nem a Mualem-van Genuchten összefüggést, hanem a Campbell-függvény módosított alakját használja, így a vizsgált térképi adatbázisok tesztelésére közvetlenül nem alkalmas.

A levélfelületi index (LAI, 1. ábra) időbeli becslését Szalafö esetében nehezítette, hogy a gyepet rendszeresen, de nem ismert időközönként és mértékben vágják. Fiadon a LAI maximális értékét levélgyüjtéssel (5 db $0,25 \mathrm{~m}^{2}$-es keretben) becsültük (BRÉDA, 2003). A LAI éven belüli szezonális változását a MODIS mühold 16 napos vegetációs index felvételeiből becsültük (WANG et al. 2005). A gyökérzóna maximális mélysége Szalafön $60 \mathrm{~cm}$, Fiadon $150 \mathrm{~cm}$ volt. A gyökérsürüség talajmélység szerinti megoszlását részben a szelvényfeltárások alapján, részben kalibrációval állítottuk be. A telítésközeli és az erősen kiszáradt talajállapotok növényi vízfelvételre gyakorolt hatását mindkét helyen a Feddes-féle stressz-függvénnyel (FEDDES et al. 1978) vettük figyelembe. A stressz-függvények paramétereit Szalafön a Hydrus-1D legelőkre vonatkozó ajánlása szerint, míg Fiadra kalibráció útján állítottuk be. A hóakkumuláció és a hóolvadás figyelembe vételének feltétele a hötranszportot leíró egyenlet megoldása, amihez a Hydrus-1D program alapértelmezett beállításait és paraméterezését használtuk.

\section{A szimulációkban vizsgált talajhidrológiai paraméterek}

Az egyes modellváltozatok kizárólag a talajhidrológiai paraméterezésükben tértek el. A szimulációkhoz bemeneti információként a víztartóképesség-görbét leíró függvény paramétereire ((2) egyenlet) és a hidraulikus vezetőképességre volt szükség. A vízforgalmi szimulációkat az alábbi eltérő pontosságú talajhidrológiai paraméterekkel végeztük el:

(1) REF: a talaj laboratóriumban mért víztartó- és telített vízvezető képesség adataiból kalibráció-validáció során kapott értékekkel ("legjobbnak vélt" verzió),

(2) MEAS_SHP: a talaj laboratóriumban mért víztartó- és telített vízvezetó képesség adataival,

(3) MEAS_EU-PTF: a talaj laboratóriumban meghatározott alaptulajdonságai alapján, az EU-PTF-ekkel (TóTH et al., 2015) számított talajhidrológiai paraméterekkel, 
(4) HUN-MAP_EU-PTF: a hazai DOSoReMI talajtérképek (Digital, Optimized Soil Related Maps and Information; PÁsZTOR et al., 2018b) alapján az EU-PTFekkel számított talajhidrológiai paraméterekkel, illetve

(5) EU_SHG: az EU-SoilHydroGrids (TóTH et al., 2017) térképek vizsgált talajszelvényekre vonatkozó talajhidrológiai adataival.

Az (1)-(5) modellváltozatokban a talajréteghatárokat a következők szerint adtuk meg:

- REF-nél mért és kalibrált értékek,

- MEAS_SHP és MEAS_EU-PTF-nél mért értékek,

- HUN-MAP_EU-PTF-nél DOSoReMI adatbázis alapján,

- EU_SHG-nél EU-SoilHydroGrids adatbázis alapján.

Az (1) REF változat kidolgozása a terepi és laboratóriumi adatokon alapul, amik közül több jellemzőt kalibráció-validáció keretében módosítottunk (lásd a következő alfejezet). Ezért ezt a verziót tekintjük a valóság Hydrus-1D-ben elérhető legjobb leképezésének. Egyben kiindulási alapot is jelentett a további modellépítéshez, mert a (2)-(5) konfigurációkat ebből a változatból, a talajréteghatárok és a talajhidrológiai paraméterek módosításával állítottuk elő.

A (4) HUN-MAP_EU-PTF modellváltozathoz a 0-30, 30-60 és 60-90 cm-es talajmélységekre $100 \mathrm{~m}$ felbontásban számítottuk ki a talajhidrológiai paramétereket, majd rendeltük hozzá a becsült értékeket a vizsgált talajszelvényhez. $\mathrm{Az}$ európai talajhidrológia szelvényadatbázis (EU-HYDI) megbízhatósági számításokra elkülönített részén az EU-PTF-ek átlagos négyzetes hibájának gyöke $0,067 \mathrm{~cm}^{3} / \mathrm{cm}^{3}$ a víztartóképesség-görbe esetén, $1,09 \mathrm{~cm} /$ nap a telített vízvezető képességre (TóTH et al., 2015).

A modellváltozatok jóságát a különböző mélységekben mért és számított talajnedvesség-idősorok összevetésével jellemeztük (lásd a következő alfejezet). Emellett vizsgáltuk, hogy a talajhidrológiai paraméterezés változása hogyan befolyásolja az egyes vízmérleg komponensek alakulását (tényleges evapotranszspiráció, felszíni lefolyás, talajba szivárgás, mélybe szivárgás, vízkészletváltozás). A mintaterületeken ezekre a vízforgalmi összetevőkre nem zajlik célzott monitoring, így a mérésen alapuló ellenőrzési lehetöség hiányában ezekre az (1) REF-hez hasonlítottuk a további modellváltozatok eredményeit.

\section{Kalibráció-validáció, modellhatékonyság}

A kalibráció során az (1) REF modellváltozat több paraméterének módosításával a mért és számított talajnedvesség-idősorok közti eltérést minimalizáltuk. Ehhez Szalafö esetén a 2014. év, Fiad esetén a 2016. év mérési adatait használtuk. Az illeszkedést több modellhatékonysági mutató segítségével jellemeztük ( ${ }^{2}$, RMSE, NSME), melyek közül az NSME-t alkalmaztuk célfüggvényként. A mutatókról röviden:

- A meghatározottsági együttható $\left(\mathrm{R}^{2}\right)$ megmutatja, hogy a mért idősor változását milyen mértékben magyarázza a számított idősor. Értéke a két idősor 
korreláltságát jellemzi ( 0 - nincs statisztikai kapcsolat; 1 - tökéletes korreláció), a szisztematikus alul-, illetve felülbecslésekről nem ad információt.

- A négyzetes hiba-idősor átlagának gyöke (Root Mean Square Error - RMSE) szintén a számítás hibáját jellemzi. Nullához közeli értéke arra utal, hogy a mért és számított adatok ugyanabból a valószínűségi eloszlásból származnak.

- A Nash-Sutcliffe modellhatékonysági tényező (Nash-Sutcliffe Model Efficiency NSME) a hidrológiában az egyik leginkább elfogadott mérőszám. Értéke - $\infty$ és 1 között mozog, a nullánál nagyobb érték azt jelzi, hogy a modell jobban írja le a valóságot, mint a mérések várható értéke.

Talajnedvesség esetén nincs tudomásunk olyan elfogadott irányelvről, ami a modellhatékonysági mutatók értékelését segítené. Ezért HARMEL et al. (2018) hidrológiai és vízminőségi szimulációkra vonatkozó útmutatásaira támaszkodtunk. Eszerint a NSME 0,5-nél nagyobb értéke esetén a modellilleszkedés elfogadhatónak, míg a leírt jelenségtől függően 0,66, ill. 0,75 fölött kiválónak tekinthető. A kalibrációba bevont modellparaméterek és jellemzők:

- Talajhidrológiai adatok (minden rétegre): a víztartó- és vízvezetőképesség-görbe Mualem-van Genuchten-féle paraméterei; a réteghatárok helye.

- Vegetációs jellemzők: sugárzáselnyelődési és intercepciós együtthatók, gyökérsűrüség mélység szerinti eloszlása.

A fentiek mellett célravezetőnek bizonyult a felszín közeli, biológiailag aktív, de nehezen mérhető, mintázható tartomány leképezéseként egy járulékos talajréteg alkalmazása. Ennek a víztartó- és vízvezető képesség jellemzőit szintén finom hangoltuk.

A kalibráció (Fiad - 2016; Szalafő - 2014) iteratív módon történt: annak érdekében, hogy egyszerre ne kelljen túl sok paraméterre elvégezni az erősen nem-lineáris optimalizációs feladatot, egy lépésben maximum tíz jellemzőt változtattunk. Az ezekre kapott köztes eredmények alapján a következő lépésben a paraméterek körét és tartományát módosítva újra elvégeztük az optimalizációt. Egy-egy köztes lépés során nagyságrendileg több száz szimuláció történt. A validáció során az optimálisnak tekintett paraméterkombináció rögzítésével végeztünk egy számítást a vizsgálat másik évére (Fiad - 2017; Szalafö - 2013), amelyre a modellhatékonysági mutatókat szintén meghatároztuk.

A modellváltozatok automatizált felépítését, a kalibrációt és az eredmények statisztikai értékelését a saját fejlesztésű "Batched Hydrologic Runs" (BHR.exe, KOZMA ET AL, 2014) keretprogrammal végeztük. A program a felhasználó által a több ponton mért víztartalomra vagy peremi vízforgalomra definiált globális és lokális optimalizációs problémákat az nlopt (JOHNSON, 2014) szabad hozzáférésủ programkönyvtár segítségével oldja meg. 

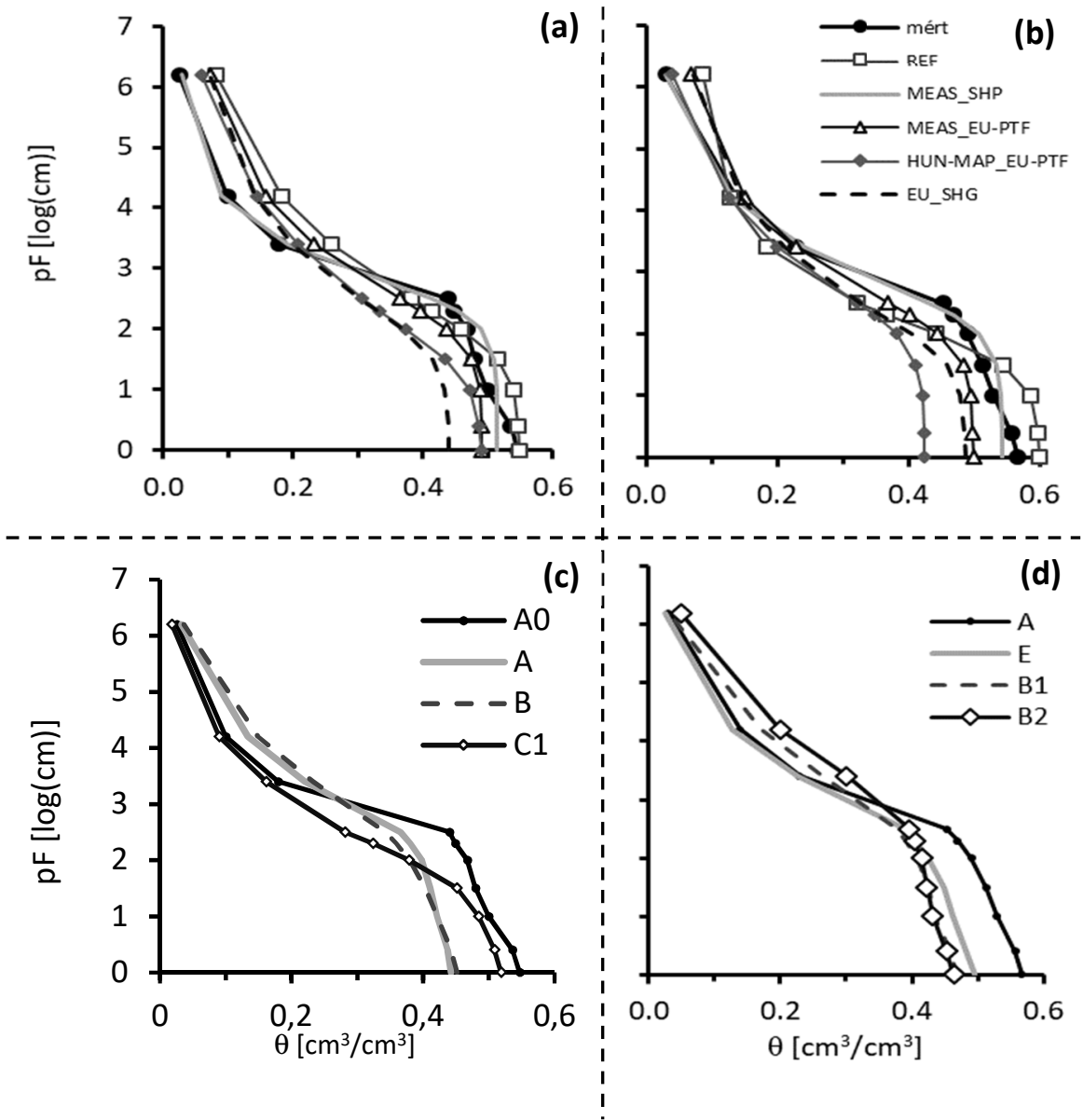

2. ábra

Víztartóképesség-görbék: a mért és a különböző módszerekkel becsült görbék - (a) Fiad, $\mathrm{A}_{0}$ szint, (b) Szalafö, A szint; a genetikai szintek mért görbéi (c) Fiad, (d) Szalafő

\section{Eredmények}

\section{Talajszelvény-feltárás}

Fiadon a talajszelvény löszön kialakult Ramann-féle barna erdőtalaj. A 130 cm-ig feltárt szelvényben öt genetikai szintet lehet elkülöníteni. Az A- és B-szintek kilúgozottak, meszet nem tartalmaznak, kémhatásuk savanyú, szerkezetük morzsás, a mélységgel csökken a szerkezeti elemek mérete. A mész $75 \mathrm{~cm}$-en jelenik meg, ahol színben, szerkezetben, tömődöttségben és a gyökerek elöfordulását tekintve is határozott az átmenet a $\mathrm{C}_{1}$-szintbe. $\mathrm{A} \mathrm{C}_{2}$-szintben mészgöbecsek is előfordulnak. A szelvény minden szintjének iszapos vályog a fizikai félesége. A talaj vízraktározó képessége jó (2. ábra), vízvezetô képessége a B-szintben igen gyenge, a többiben jó (1. táblázat) (VÁRALLYAY, 2005). 


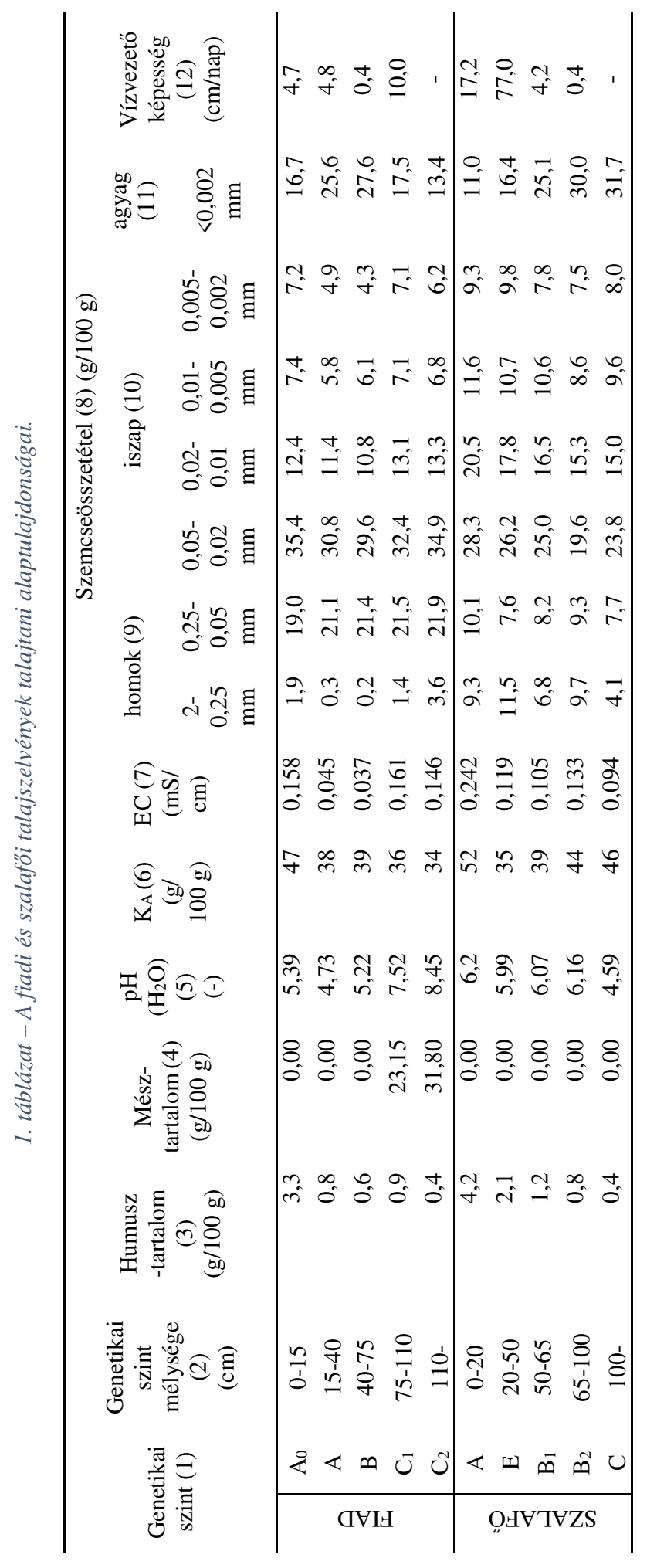


Szalafön a talaj típusa pszeudoglejes barna erdőtalaj. $120 \mathrm{~cm}$-ig öt szintre tagolódik. A felső szint (A) humuszos, apró morzsás szerkezetủ, iszapos vályog fizikai féleségü. A pszeudoglej az $\mathrm{E}$ és $\mathrm{B}_{1}$ iszapos vályog textúrájú szintekben van jelen 20 és $65 \mathrm{~cm}$ között. A $65-100 \mathrm{~cm}$ szint $\left(\mathrm{B}_{2}\right)$ erősen tömődött, fizikai félesége iszapos agyagos vályog. $65-80 \mathrm{~cm}$ és $90-100 \mathrm{~cm}$ mélységben vaskőfok fordul elő, emellett az altalaj minden szintjében található vaskiválás. A teljes szelvény mészmentes, kémhatása gyengén savanyú a C-szint kivételével, ami savanyú

A talaj térfogattömege fokozatosan növekszik a mélységgel, $1,23 \mathrm{~g} \mathrm{~cm}^{-3}$-röl (A) $1,61 \mathrm{~g} \mathrm{~cm}^{-3}$-ig $\left(\mathrm{B}_{1}\right)$. Az A- és E-szintekben a hidraulikus vezetőképesség jó, 50 $\mathrm{cm}$ alatt igen gyenge, egészen $0,4 \mathrm{~cm} /$ nap értékre csökken. A szelvény minden szintjének jó a vízraktározó képessége (2. ábra). A Balaton vízgyüjtőn a Ramann-féle barna erdőtalajoknak 10\%, a pszeudoglejes barna erdőtalajoknak $2 \%$ a területi részesedése (PÁsZTOR et al., 2018a).

\section{A talajnedvesség szimulációja}

A fiadi referencia modell kalibráció-validációja HARMEL et al. (2018) alapján elfogadhatónak/kielégítőnek tekinthető (a két évre összegzett NSME átlaga 0,49) (2. táblázat).

A paraméter illesztést az következő tényezők nehezítették. A $10 \mathrm{~cm}$ mélyen levő mérőműszer talajnedvesség adatsorát vizuális értékelés alapján a benne tapasztalható pillanatszerü ugrások/szakadások miatt hibásnak ítéltük meg (DORIGO et al., 2012). Ez azért kedvezötlen, mert ez a szonda helyezkedik el legközelebb a felszínhez, a meteorológiai folyamatok hatása itt érvényesül a legintenzívebben. A kalibráció itt a legkevésbé terhelt a mélységgel halmozódó numerikus és paraméterezési hibáktól, így az elvben legértékesebb mérési adatokat kellett kizárnunk. A nem helyben mért meteorológiai adatok szintén kedvezőtlenül hatottak a modellhatékonyságra, mivel tapasztalatunk szerint a vízforgalmi modellek kifejezetten érzékenyek a peremfeltételekre. Ezt tükrözi 2016 ősze $50 \mathrm{~cm}$ mélységben és 2017 tavasza 20 és $50 \mathrm{~cm}$ mélységekben, ahol a számolt talajnedvességek több hónapon át felülbecslik a mérteket (3. ábra). A problémát a paraméterek állításával nem lehetett kiküszöbölni, vélhetően a légköri peremfeltételek hibája miatt. Ettől eltekintve a modellezett idősorok megfelelően írják le a hóolvadás, az intenzív csapadékok és a párolgási veszteség talajnedvességre gyakorolt hatását (3. ábra). Megjegyzendő, hogy a kalibrációs és validációs időszak illeszkedése között lényeges eltérés van. Ez arra utal, hogy a modell további évek mérési adataival valószínüleg még érdemben fejleszthető. 

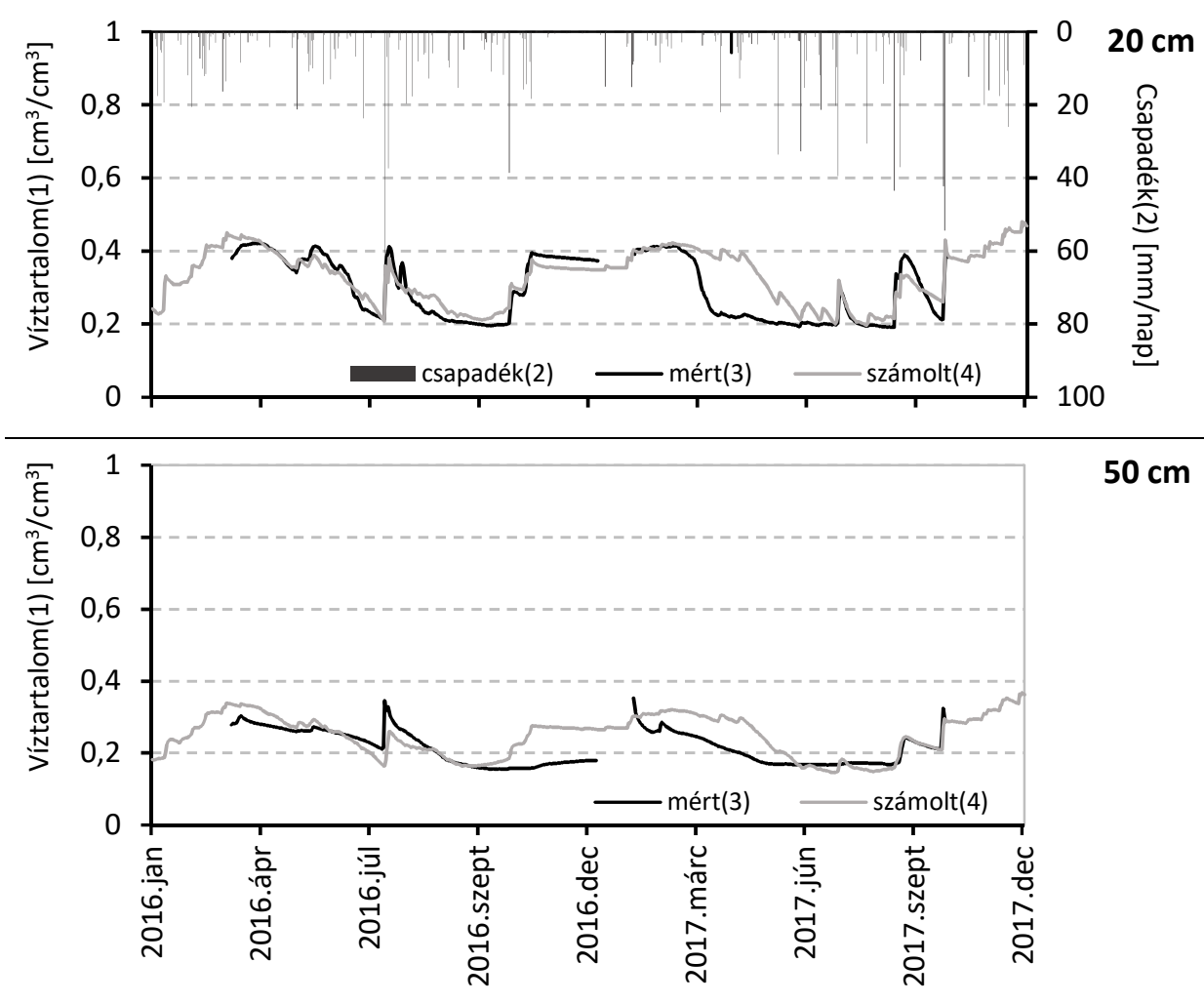

$50 \mathrm{~cm}$

3. ábra

Mért és számított víztartalom idősorok összevetése: Fiad, (1) REF modellváltozat: 2016 (kalibráció, NSME = 0.64), 2017 (validáció NSME = 0.22).

A szalafői mért és számított víztartalom-idősorok erős egyezést mutatnak. A szimulációs eredmények így a modellhatékonysági mutatók alapján kiválónak tekinthetők (2. táblázat, 4. ábra). A felszín közelében a talajnedvesség időben intenzíven változik erős összefüggésben a meteorológiai viszonyokkal. A mélységgel a talajnedvesség változékonysága jelentősen csökken, 20 , majd $40 \mathrm{~cm}$ mélyen mintegy fele akkora, mint a felszín közelében. A mérés és a szimuláció között lényeges eltérés $40 \mathrm{~cm}$ mélységben tapasztalható. Itt a mért víztartalom időben jellemzően minimális mértékben és kiegyenlítetten változik, ugyanakkor mindkét évben ugrásszerü növekedést idéz elő egy jelentős, de nem kiugró esőzés. Ezt a nagyon erősen nem-lineáris viselkedést a számítások nem tudták lekövetni. A jelenséget magyarázhatja a szelvényben megfigyelt pszeudoglejes duzzadó agyag jelenléte. Az ilyen agyagok sajátossága, hogy a víztartalom növekedésével a telítés közelében a duzzadás következtében csökken a pórusok mérete, emiatt pedig jelentősen csökken a vízvezető képességük. Ez a víztartalom és a vízvezető képesség között általánosan érvényes kapcsolattal (lásd. pl. a (3) Mualem-egyenlet) ellentétes irányú. A jelenség korrekt matematikai kezelésére ismereteink szerint az 
irodalomban elterjedt talajfizikai és vízforgalmi modellek egyike sem képes. A különbségben szintén közrejátszhat a térségben jellemző köztes lefolyás (interflow), amit az alkalmazott egydimenziós modellel nem tudtunk figyelembe venni.
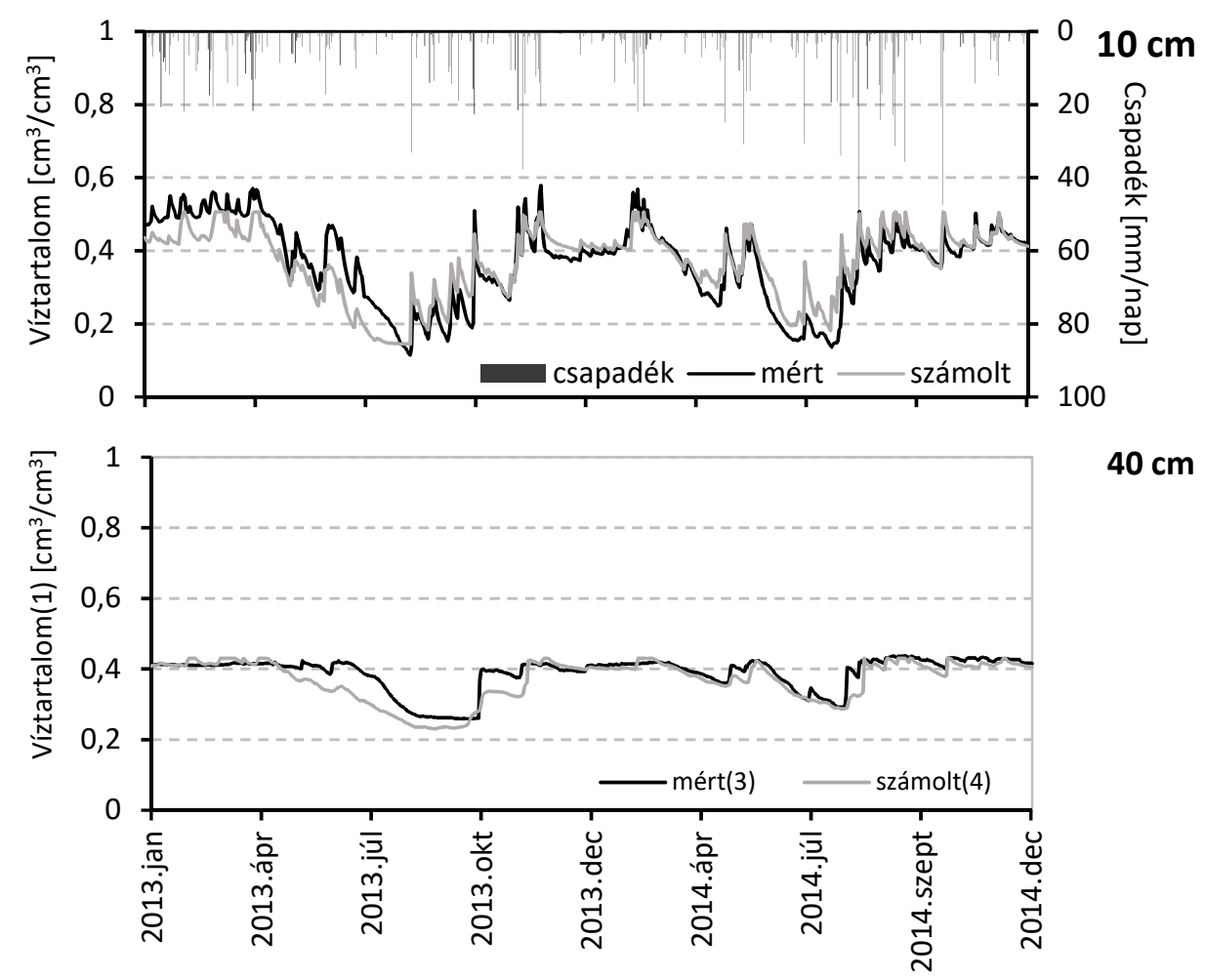

$40 \mathrm{~cm}$

4. ábra

Mért és számított víztartalom idősorok összevetése: Szalafő, (1) REF modellváltozat: 2013 (verifikáció, NSME = 0.72), 2014 (kalibráció NSME = 0.80).

Az öt vizsgált modellváltozat esetében lényegesen eltért a mért-számított talajnedvességek illeszkedése. Fiadon egyedül a kalibrált (1) REF vezetett elfogadható eredményre, a másik négy változat kifejezetten gyengének bizonyult (az NSME értékek három esetben is negatívak). Szalafő esetén minden változat pozitív NSME-vel jellemezhető. A helyszínek között két hasonlóság is megfigyelhetö:

- A várakozással ellentétben a mért talajhidrológiai jellemzőket használó (2) MEAS_SHP mutatta a legrosszabb illeszkedést.

- A kalibrált modellek után az EU-SoilHydroGrids adatbázis talajhidrológiai adatait bemeneti információként használó (5) EU_SHG változatok voltak a legeredményesebbek. 
2. táblázat

A modellváltozatok eredményei: modellhatékonysági mutatók

\begin{tabular}{ll|ccc|ccc}
\hline \multicolumn{2}{c|}{ Modellváltozat(1) } & \multicolumn{3}{|c|}{ FIAD } & \multicolumn{3}{c}{ SZALAFÖ } \\
\hline \multirow{2}{*}{ ID } & NSME & RMSE & $\mathrm{R}^{2}$ & NSME & RMSE & $\mathrm{R}^{2}$ \\
& & {$[-]$} & {$[\%]$} & {$[-]$} & {$[-]$} & {$[\%]$} & {$[-]$} \\
\hline 1 & REF & 0,49 & 4,48 & 0,77 & 0,75 & 4,17 & 0,89 \\
2 & MEAS_SHP & $-0,94$ & 8,70 & 0,50 & 0,24 & 6,74 & 0,85 \\
3 & MEAS_EU-PTF & $-0,29$ & 7,11 & 0,70 & 0,43 & 5,85 & 0,84 \\
4 & HUN-MAP_EU-PTF & $-0,35$ & 7,24 & 0,69 & 0,42 & 5,90 & 0,89 \\
5 & EU_SHG & 0,13 & 5,83 & 0,59 & 0,67 & 4,35 & 0,89 \\
\hline
\end{tabular}

Ezt Fiad talajmintái esetében a vízvezető képességek mérése során tapasztalt nagyságrendi bizonytalanság magyarázza. A számítások erre a nehezen mérhető és rendkívül változékony (FODOR et al., 2009) paraméterre a leginkább érzékenyek, mivel annak a teljes vízmérlegre döntő hatása van (lásd. a következő fejezet). A (2) MEAS_SHP-ben alkalmazott mért vízvezető képességek Fiadon a mélységtől függően akár egy-két nagyságrenddel is kisebbek, mint bármelyik másik modellváltozat értékei.

\section{Vizforgalmi összetevők}

A szimulációkból levezetett vízmérlegek - összhangban az eltérő környezeti adottságokkal - a két helyszín között lényeges különbséget mutatnak: míg Fiadon a vízveszteségi oldalon a párolgás volt a meghatározó, addig Szalafőn a felszíni lefolyás és a mélybe szivárgás szerepe is jelentős volt. Az egyes modellváltozatok Fiad esetén közel hasonló képet adtak a vízforgalomról, ezzel szemben Szalafón a különböző talajparaméterekre számottevő eltérések adódtak. A számolt vízmérlegeket a helyszínenként vizsgált két év éves átlagaival mutatjuk be (5. ábra).

A szabadtéri csapadékösszeg és a PET Fiadon $794 \mathrm{~mm} / \mathrm{év}^{\mathrm{s}} \mathrm{e} 750 \mathrm{~mm} / e ́ v$, míg Szalafőn $905 \mathrm{~mm} / \mathrm{év}_{\mathrm{v}}$ és $640 \mathrm{~mm} / e ́ v$ volt. A két helyszínen a talajparaméterektől független intercepció a csapadéknak rendre 20\%-át, illetve 12\%-át tartotta vissza. A további vízmérleg komponensekre az öt modellváltozat átlagát véve az alábbi igaz:

- Fiadon a felszíni lefolyás elhanyagolható, értéke egyedül a (2) MEAS_SHP változatnál volt számottevő. A talajba jutó csapadék (616 mm/év) döntő hányada ( 84\%-a) párolgás révén visszajutott a légkörbe, míg 15\%-a a talajprofilban tárolt nedvességkészletet növelte.

- Szalafón a szabadtéri csapadék 8\%-a távozott felszíni lefolyásként (modellváltozatonként jelentős különbséggel). A talajba 690 mm/évnyi csapadék jutott, az aktuális evapotranszspiráció 405 mm/év (beszivárgáshoz mérten 59\%) volt, emellett $302 \mathrm{~mm} / \mathrm{e} v$ (45\%) mélybe szivárgás adódott. A tárolt nedvességkészlet $25 \mathrm{~mm} / \mathrm{é}_{\mathrm{v} v e l}(4 \%$-kal) csökkent. 
- A számítások relatív anyagmérleg hibája a peremi vízforgalomra vetítve elfogadható mértékü, Fiadon 2\%, Szalafőn $1 \%$.
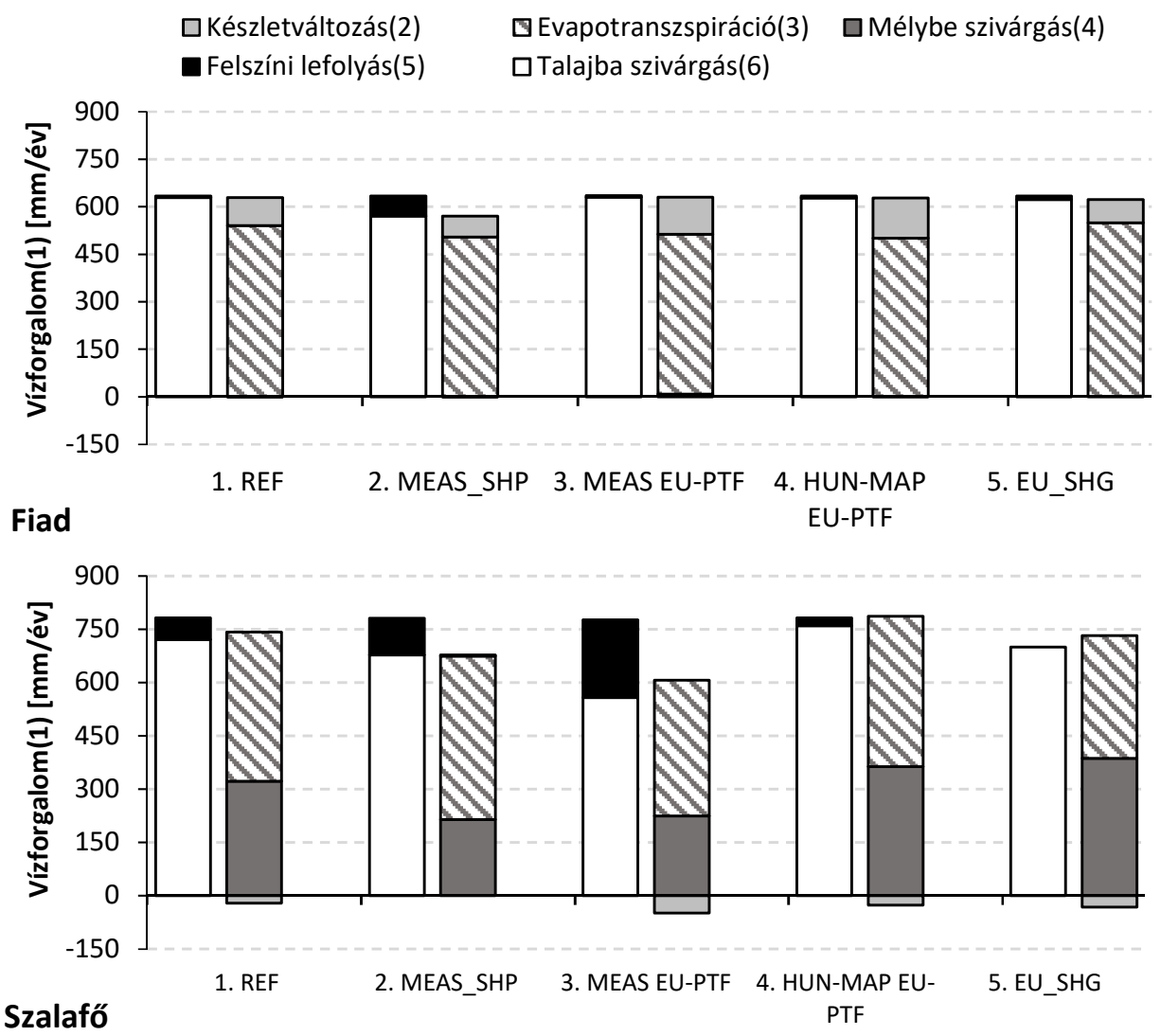

5. ábra

A modellváltozatok átlagos vízforgalmi összetevői: az első oszlopok a talajt elérő csapadék útját mutatják (beszivárgás, lefolyás), a második oszlopok a talajban lezajló hidrológiai folyamatok eredményét (párolgás és növényi vízfelvétel, mélybe szivárgás, készletváltozás). $\mathrm{Az}$ ábrán az átláthatóság érdekében az intercepciót és annak párolgását nem tüntettük fel.

Az öt modellváltozat vízmérlege közül Fiad esetében a (2) MEAS_SHP tért el érdemben a többitől, ami összhangban van a modellhatékonysági mutatókkal. Az eltérést a vízvezető képesség meghatározását terhelő bizonytalanságok magyarázhatják. Szalafő esetében nem fedezhető fel egyértelmü kapcsolat a talajnedvességek alapján levezetett modellhatékonyság (2. táblázat) és a vízforgalom alakulása (5. ábra) között: míg például az (1) REF érdemi ( 10\%-nyi) lefolyásra vezetett, addig a jósági rangsorban következő (5) EU_SHG esetén az összes talajt elérő csapadék be tudott szivárogni. A Szalafőre becsült lefolyás széles tartományban mozgott, ami rámutat az egyes talajparaméterezési módszerek közti eltérésre. A lefolyás értéke 0 és 219 mm/év (a talajt elérő csapadék 0-28\%-a) között 
változott. Ez elsősorban az egyes modellváltozatokban használt vízvezető képességek nagyságrendi különbségeire vezethető vissza, mivel a talajba szivárgás mértékét döntően (de nem kizárólag) ez a paraméter határozza meg.

\section{Következtetések}

1. A Fiadra és Szalaföre kapott eredmények rámutatnak, hogy a modellezés sikerességét a peremfeltételként és az ellenőrzéshez használt hidrometeorológiai mérési adatok nagymértékben meghatározzák. Ezek hibáit a talajparaméterek illesztésével nem lehet - és nem is helytálló - ellensúlyozni

2. Míg Fiadon az adatbizonytalanság (lásd előző pont), addig Szalafőn a duzzadó agyag jelenléte és a feltételezett oldalirányú szivárgás nehezítette a modellkalibrációt. A duzzadó agyagok telítetlen szivárgásra gyakorolt hatása rendhagyó, mivel a telítéssel a vízvezető képesség csökken, nem növekszik (CuI et al., 2008). A jelenséget az elterjedt számítási algoritmusok egyelőre nem tudják helyesen kezelni, kutatási szempontból ez egy nyitott kérdéskör. A probléma jövőbeni vizsgálatára Szalafố alkalmas helyszínnek ígérkezik.

3. A referenciának tekintett kalibrált modellváltozat után mindkét helyszínen az EU-SoilHydroGrids adatai biztosították a mért és számított talajnedvességek legjobb illeszkedését. Ez biztató eredmény a vízgyüjtő szintü hidrológiai becslések szempontjából, hiszen ezen a léptéken épp a talajhidrológiai adatok meghatározása jelenti az egyik fő bizonytalansági forrást. A szelvényszinten, pontszerủen elért kedvező eredményeink erösítik azt a feltételezést, hogy a pedotranszfer függvényeken alapuló újszerü talajhidrológiai adatbázisok nagyobb léptéken is megbízható becslésekre vezethetnek.

4. A várakozásokkal ellentétben mindkét helyszínen a mért talajhidrológiai paraméterek eredményezték a legrosszabb illeszkedést, amit a vízvezető képesség meghatározását terhelö bizonytalanságokkal magyarázunk. A tapasztalat hátterében vélhetően az a tény áll, hogy a talajtani gyakorlatban elterjedt szelvényleírás és mintázás - érthető módon - nem a hidrológiai szimulációk adatigényeihez igazodik.

5. Mivel a két vizsgált helyszínen egymással ellentétes eredmények adódtak, nem állapítható meg egyértelműen, hogy a talajnedvesség vagy a vízmérleg számítása érzékenyebb-e a talajtani paraméterezésre. Ennek eldöntéséhez a kutatás hátralevő részében (i) hosszabb időszakokat és (ii) több helyszínt tervezünk vizsgálni és (iii) nagyobb figyelmet fordítunk a talajnedvesség-szenzorok kalibrációjára. A további mérőhelyek bevonását indokolja az is, hogy a vízgyüjtőn megtalálható területhasználatokról és talajokról átfogóbb képet kaphassunk.

6. A fentiek megerősítik azt a két modellezési alapvetést, hogy (i) a szimulációs módszertant a vizsgálat céljához és léptékéhez kell igazítani, továbbá (ii) a szimulációk csak megfelelő kalibráció-validáció esetén tekinthetők megbízhatónak. 


\section{Összefoglalás}

A folyamatalapú hidrológiai számításoknak és az azokra épülő vízminőségi, ökológiai elemzéseknek jelentős a bemenő adatigénye, ami a jövőben várhatóan tovább növekszik. A méréstechnológia rohamos fejlődésével a hidrológiai modellek bemenő adatai közül mára a szük keresztmetszetet lokális és vízgyüjtő léptéken is a felszín alatti viszonyok, és elsősorban a talajok szivárgáshidraulikai tulajdonságainak számszerüsítése jelenti. A helyzetet felismerve a közelmúltban különböző módszertannal több talajtani, talajhidrológiai adatbázist is kidolgoztak. Kutatásunkban azt vizsgáljuk, hogy a 100 m felbontású hazai talajadatok és európai becslő algoritmusok alapján számított talajhidrológiai paraméterek (i) megbízható bemeneti adatforrást biztosítanak-e, és (ii) a korábban rendelkezésre álló adatállományokhoz képest javítják-e a hidrológiai számítások jóságát talajszelvény szintủ vízforgalmi modellben.

Az Erdészeti Tudományos Intézet (NAIK ERTI) két mintaterületén (Fiad és Szalafö) mért meteorológiai és talajnedvesség-idősorok segítségével 5-5 darab talajszelvényszintủ vízforgalmi modellváltozatot állítottunk fel Hydrus-1D környezetben. Ezek kizárólag a talajtani paraméterezésükben (réteghatárok helye, telített vízvezető képesség és retenciós görbe együtthatók) tértek el: a talajrétegek jellemzésére felhasználtuk (i) a kalibráció-validáció eredményeit ("legjobbnak vélt" verzió), (ii) a helyszíni mintavételből származó laboratóriumi méréseket, (iii) a mért talajtulajdonságok alapján, az európai becslő függvényekkel (EU-PTF) számított talajhidrológiai tulajdonságokat, (iv) a hazai DOSoReMI adatbázis alapján, az EUPTF-ekkel számított talajhidrológiai tulajdonságokat, illetve (v) az EUSoilHydroGrids térképeket. A modellváltozatokat a mért és számított talajnedvesség-idősorok összevetése (NSME, RMSE, $\mathrm{R}^{2}$ ) alapján értékeltük. Emellett összehasonlítottuk a számított vízmérlegeket is.

$\mathrm{Az}$ öt-öt modellváltozat esetében lényegesen eltért a mért-számított talajnedvességi idősorok illeszkedése. Fiadon egyedül a kalibráció adott elfogadható eredményt $(\mathrm{NSME}=0.49$ ), a másik négy változat kifejezetten gyengének bizonyult (három esetben NSME < 0). Szalafőn minden változat pozitív NSME-re vezetett, a kalibráció kiválónak tekinthető $(\mathrm{NSME}=0.75)$. A várakozással ellentétben a mért talajhidrológiai paraméterekre épülő modellváltozatok adták a legrosszabb illeszkedést, míg a hatékonysági rangsorban a kalibrált modellek után az EU-SoilHydroGrids változatok következtek. A szimulációkból levezetett vízmérlegek Fiadon csak kevéssé, míg Szalafön nagymértékben függtek a talajparaméterezéstöl. A vizsgálat fontos tapasztalata, hogy a talajszelvény feltárás gyakorlata - érthető módon - elsősorban nem a hidrológiai modellezés szempontjaihoz igazodik, így az adatbizonytalanság forrása lehet. A vizsgálat eredményei alapján folytatjuk a Balaton vízgyüjtő talajhidrológiai paramétereinek 3D térképezését.

Kulcsszavak: talajnedvesség; talajhidrológiai paraméterek; Hydrus-1D; vízforgalom 


\section{Köszönetnyilvánítás}

A kutatáshoz nyújtott segítségéért, tanácsaiért köszönetünket fejezzük ki Illés Gábornak (NAIK ERTI). A kutatás a Nemzeti Kutatási, Fejlesztési és Innovációs Hivatal támogatásával az NKFI Alapból (KH-124765) és a Bolyai János Kutatási Ösztöndíj, ill. a K119475. sz. NKFI pályázat támogatásával valósult meg.

\section{Irodalom}

Arnold, J.G., D. N. Moriasi, P. W. Gassman, K. C. AbBaspour, M. J. White,R. SRinivasan, C. SANTHI, R. D. HARMEl, A. VAN Griensven, M. W. VAN LIEW, N. KANNAN, M. K. JHA. (2012). SWAT: Model use, calibration, and validation. Transactions of the ASABE. Vol. 55(4). 1491-1508.

BAKACSI, Z., PÁSZTOR, L., SzABÓ, J., KUTI, L., LABORCZI, A., (2012) 3D textúra adatbázis létrehozása indikátor-krigeléssel, talajtani és agrogeológiai adatbázisok egységesítésével. Agrárinformatika / Agricultural Informatics (2012) Vol. 3, No. 1:46-51.

BRÉDA, N.J. (2003) Ground-based measurements of leaf area index: a review of methods, instruments and current controversies. J. Exp Bot. 2003 Nov; 54. (392). 2403-2417. DOI: 10.1093/jxb/erg263

BUZÁS I. (szerk.), 1988. Talaj- és agrokémiai vizsgálati módszerkönyv 2. A talajok fizikai-kémiai és kémiai vizsgálati módszerei. Mezőgazdasági Kiadó. Budapest.

BuZÁs I. (szerk.), 1993. Talaj- és agrokémiai vizsgálati módszerkönyv 1. A talaj fizikai, vízgazdálkodási és ásványtani vizsgálata. Inda 4231 Kiadó. Budapest. 357.

Chaney, N. W., Wood, E. F., McBratney, A. B., Hempel, J. W., Nauman, T. W., Brungard, C. W. AND Odgers, N. P. (2016) POLARIS: A 30-meter probabilistic soil series map of the contiguous United States, Geoderma, 274. 54-67, doi:10.1016/j.geoderma.2016.03.025

Cui, Y. J., Tang, A. M., Loiseau, C., Delage, P. (2008) Determining the unsaturated hydraulic conductivity of a compacted sand-bentonite mixture under constant-volume and free-swell conditions, Phys. Chem. Earth, 33. 462-471.

DaI, Y., Shangguan, W., Duan, Q., LiU, B., Fu, S. And NiU, G.-Y. (2013) Development of a China Dataset of Soil Hydraulic Parameters using pedotransfer functions for land surface modeling, J. Hydrometeorol., 14. (3). 869-887, doi:10.1175/JHM-D-12-0149.1

Dorigo, W.A., Xaver, A., Vreugdenhil, M., Gruber, A., Hegyiová, A., SANChis-Dufau, A.D., Zamojski, D., Cordes, C., WAGNER, W., Drusch, M. (2012) Global automated quality control of in situ soil moisture data from the international soil moisture network. Vadose Zone Journal; 12. (3). vzj2012.0097. 
FARKAS, C., Hernádi, H., MAKÓ, A., MÁtÉ, F. (2011) Estimating climate change effects on soil water balance elements of Hungarian calcic chernozem soils. Agrokémia és Talajtan, 60. 41-56.

Feddes R A, Kowalik P J, Zaradny H (1978) Simulation of Field Water Use and Crop Yield. John Wiley \& Sons, New York, NY.

FEDERER, C.A. (2002) BROOK 90: A simulation model for evaporation, soil water, and streamflow. http://www.ecoshift.net/brook/brook $90 . h t m$

Fiala, K., Blanka, V., Ladányi, Z., Szilassi, P., Benyhe, B., Dolinaj, D., PÁLFAI, I., (2014) Drought severity and its effect on agricultural production in the Hungarian-Serbian cross-border area. Journal of Environmental Geography 7. (3-4). 43-51. doi: 10.2478/jengeo-2014-0011

FODOR, N., BLASKÓ, J., ÉRI, L., RAJKAI, K. (2009) Hidraulikus vezetőképesség mérési és becslési eredmények összehasonlítása homoktalajra. Agrokémia és Talajtan 58. (2). 369-380.

FODOR, N., PÁszTOR, L., NÉMETH, T. (2014) Coupling the 4M crop model with national geo-databases for assessing the effects of climate change on agroecological characteristics of Hungary. International Journal of Digital Earth, 7(5), 391-410, https://doi.org/10.1080/17538947.2012.689998

GANOt, Y., Holtzman, R., Weisbrod, N., NitZAN, I., KATZ, Y., KuRTZMAn, D. (2017) Monitoring and modeling infiltration-recharge dynamics of managed aquifer recharge with desalinated seawater. Hydrol. Earth Syst. Sci., 21. 44794493, 2017. https://doi.org/10.5194/hess-21-4479-2017

GRIBOVSZKI, Z., KALICZ, P., KUCSARA, M. (2006) Streamflow characteristics of two forested catchments in Sopron Hills. Acta Silvatica et Lignaria Hungarica, 2. $81-92$

Harmel, R.D., Baffaut, C., Douglas-Mankin, K. (2018) Review and development of ASABE Engineering Practice 621: "Guidelines for calibrating, validating, and evaluating hydrologic and water quality models" Transactions of the ASABE. 61. (4). 1393-1401. doi: 10.13031/trans.12806

JoHnSON, S. G. (2014), The NLopt nonlinear-optimization package, http://abinitio.mit.edu/nlopt

KARIMI, P., BASTIAANSSEN, W. G. M. (2015) Spatial evapotranspiration, rainfall and land use data in water accounting - Part 1: Review of the accuracy of the remote sensing data. Hydrol. Earth Syst. Sci., 19. 507-532, 2015.

KISS, K. A., GRIBOVsZKI, Z., KALICZ, P. (2005) Rainfall interception by forest canopy and forest litter in three different forest ecosystems at the eastern border of the Alps. Geophysical Research Abstracts, 7. 05430

KozMA Zs., ÁCs T., KonCSOS L. (2014) Unsaturated zone modelling - The role of soil database classification. In: C A Brebbia, H Bjornlund (szerk.) Sustainable Irrigation and Drainage V. (WIT Transactions on Ecology and the Environment; 185.) pp. 197-208. 
Marthews, T. R., Quesada, C. A., Galbraith, D. R., Malhi, Y., Mullins, C. E., HoDNETT, M. G. AND DHARSSI, I. (2014) High-resolution hydraulic parameter maps for surface soils in tropical South America, Geosci. Model Dev., 7. (3). 711-723, doi:10.5194/gmd-7-711-2014

MazZaCAVAllo MG, Kulmatiski A (2015) Modelling water uptake provides a new perspective on grass and tree coexistence. PLoS ONE 10. (12). e0144300. doi:10.1371/journal.pone.0144300

Mohanty, B.P.; Cosh, M.H.; LAKSHMi, V.; MontzKa, C. (2017) Soil moisture remote sensing: State-of-the-science. Vadose Zone J. 2017, 16. 1-9. doi:10.2136/vzj2016.10.0105

MontzKa, C., Herbst, M., Weihermüller, L., Verhoef, A. And Vereecken, H. (2017) A global data set of soil hydraulic properties and sub-grid variability of soil water retention and hydraulic conductivity curves, Earth Syst. Sci. Data, 9. (2). 529-543, doi:10.5194/essd-9-529-2017

MONTEITH, J.L. (1965): Evaporation and the environment. Symposium of the Society of Experimental Biology, 19. 1579-1590

Móricz, N., MÁtyÁs, C., BERKI, I., RAsZTovits, E., VEKERdy, Z., GRIBOVSZKi, Z. (2012) Comparative water balance study of forest and fallow plots. iForest Biogeosciences and Forestry, 5. (4). 188-196 DOI: 10.3832/ifor0624-005

MSZ-08-0205-78. MÉM Ágazati Szabvány 1979. A talaj fizikai és vízgazdálkodási tulajdonságainak vizsgálata, Budapest.

Nemes, A., SchaAp, M. AND WÖSTEN, J. (2003) Functional evaluation of pedotransfer functions derived from different scales of data collection, Soil Sci. Soc. Am. 67. 1093-1102.

PÁszTOR, L., LABORCZI, A., BAKACSI, Z., SzABÓ, J., ILLÉS, G. (2018a) Compilation of a national soil-type map for Hungary by sequential classification methods, Geoderma, 311. 93-108.

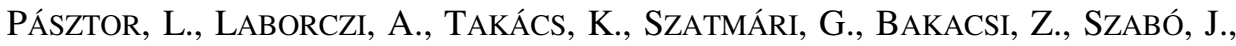
ILLÉS, G., (2018b) DOSoReMI as the national implementation of GlobalSoilMap for the territory of Hungary, In: D. ArrouAY, I. SAVIN, J. LeEnaArs, A. B. McBratney (eds.), Proceedings of the Global Soil Map 2017 Conference, July 4-6, 2017, CRC Press, Moscow, Russia, pp. 17-22,

PrÁvetz, T., SiPOS, Gy., BenyHe, B., ViKTória BlankA, V., (2015) Modelling runoff on a small lowland catchment, Hungarian great plains, Journal of Environmental Geography, 8. (1-2). 49-58. DOI: 10.1515/jengeo-2015-00

Qu, W., Bogena, H. R., Huisman, J. A., Schmidt, M., Kunkel, R., Weuthen, A., Schiedung, H., Schilling, B., Sorg, J., Vereecken, H. (2016) The integrated water balance and soil data set of the Rollesbroich hydrological observatory, Earth Syst. Sci. Data, 8. 517-529.

Scanlon, B. R., M. Christman, R. C. Reedy, I. Porro, J. SimuneK, And G. N. FLERCHINGER (2002), Intercode comparisons for simulating water balance of surficial sediments in semiarid regions, Water Resour. Res., 38. (12). 1323. 
SimuneK, J., Sejna, M., VAn Genuchten, M.T., (1998) The HYDRUS-1D software package for simulating the one-dimensional movement of water, heat and multiple solutes in variably-saturated media: version 2.0 IGWMC-TPS-70. International Groundwater Modeling Center, Colorado School of Miners, Golden, 1998.

Tóth, B., Weynants, M., Nemes, A., Makó, A., Bilas, G. And Tóth, G. (2015) New generation of hydraulic pedotransfer functions for Europe. Eur. J. Soil Sci., 66. (1). 226-238, doi:10.1111/ejss.12192, 2015.

Tóth, B., Weynants, M., PÁszTor, L., Hengl, T. (2017) 3D soil hydraulic database of Europe at $250 \mathrm{~m}$ resolution. Hydrological Processes. 31. 2662-2666.

Trodahl, M.I., Jackson, B.M., DeslipPe, J.R., Metherell, A.K. (2017) Investigating trade-offs between water quality and agricultural productivity using the Land Utilisation and Capability Indicator (LUCI) - A New Zealand application. Ecosystem Services, 26. Part B. 388-399, https://doi.org/10.1016/j.ecoser.2016.10.013.

Van LoOy, K., Bouma, J., Herbst, M., Koestel, J., Minasny, B., Mishra, U., Montzka, C., Nemes, A., PaChepsky, Y. A., PAdarian, J., SchaAP, M. G., Tóth, B., Verhoef, A., Vanderborght, J., Van Der Ploeg, M. J., WeIHERMÜLleR, L., ZACHARIAS, S., ZHANG, Y. AND VEREECKEN, H. (2017) Pedotransfer functions in Earth system science: Challenges and perspectives, Rev. Geophys., 55. (4). 1199-1256, doi:10.1002/2017RG000581

VÁRALlYAY, G. (2015) Magyarország talajainak vízraktározó képessége, Agrokémia és Talajtan, 54. (1-2). 5-24.

Vereecken, H., A. Schnepf, J.W. Hopmans, M. JaVauX, D. OR, T. Roose, J. VANDERborght, M.H. Young, W. Amelung, M. AitKenheAD, S.D. Allison, S. Assouline, P. BaVeye, M. Berli, N. Brüggemann, P. Finke, M. Flury, T. Gaiser, G. Govers, T. Ghezzehei, P. Hallett, H.J. Hendricks FransSEn, J. HePPell, R. HoRn, J.A. Huisman, D. JACQUes, F. Jonard, S. Kollet, F. LAFOlie, K. Lamorski, D. Leitner, A. McBratney, B. Minasny, C. MONTZKa, W. NOWAK, Y. PACHEPSKY, J. PADARIAN, N. Romano, K. Roth, Y. Rothfuss, E.C. Rowe, A. SCHWEN, J. ŠIMŮNeK, A. TIKTAK, J. VAN DAM, S.E.A.T.M. VAN DER ZEE, H.J. VOGEL, J.A. VRUGT, T. WÖHLING, AND I.M. YouNG. (2016) Modeling soil processes: Review, key challenges, and new perspectives. Vadose Zone J. 15. doi:10.2136/vzj2015.09.0131

Vereecken, H., Diels, J., VAN Orshoven, J., Feyen, J. AND Bouma, J. (1992) Functional evaluation of pedotransfer functions for the estimation of soil hydraulic properties, Soil Sci. Soc. Am. J., 56. 1371-1379.

WAng, Q., ADIKU,S., Tenhunen,J., Grainer,A. (2005) On the relationship of NDVI with leaf area index in a deciduous forest site. Remote Sensing of Environment, 94: 244-255.

WU, X., LU, G. AND WU, Z. (2018) An integration approach for mapping field capacity of china based on multi-source soil datasets, Water, 10. (6). 728. 
ZHAO, H., ZENG, Y., LV, S. AND SU, Z. (2018) Analysis of soil hydraulic and thermal properties for land surface modeling over the Tibetan Plateau, Earth Syst. Sci. Data, 10. (2). 1031-1061, doi:10.5194/essd-10-1031-2018

\title{
Evaluation of estimated soil hydraulic parameters at two forestry monitoring sites
}

\author{
$1 *$ Z. KozMa, ${ }^{1}$ B. Decsi, ${ }^{2}$ M. Manninger,${ }^{2}$ N. Móricz, ${ }^{3,4}$ A. MaKó, ${ }^{3,4}$ B. Szabó \\ ${ }^{1}$ Department of Sanitary and Environmental Engineering, Budapest University of \\ Technology and Economics, Budapest \\ ${ }^{2}$ Forest Research Institute, National Agricultural Research and Innovation Centre, \\ Sárvár \\ ${ }^{3}$ Institute for Soil Sciences and Agricultural Chemistry, Centre for Agricultural \\ Research, Hungarian Academy of Sciences, Budapest \\ ${ }^{4}$ Georgicon Faculty, University of Pannonia, Keszthely
}

The input data requirement of eco-hydrological models poses a growing challenge. Among the various input data the bottleneck seems to be the highresolution quantification of soil hydraulic parameters. Recognising the situation, novel soil- and soil-hydrologic databases (e.g. MARTHA, DOSoReMi, Lucas, EUSoilHydroGrids) were recently developed with different spatial characteristics (point or spatial datasets, various resolution). We aim to investigate at the soil profile level (i) the reliability of a currently implemented 3D soil hydraulic database of the Lake Balaton watershed (Hungary) and (ii) whether it improves the performance of hydrological calculations compared to some of the previously available data sets.

Our analysis was carried out for two monitored sites (Szalafö - meadow, 2013-2014; Fiad - mixed oak-beech forest, 2016-2017) located in the catchment. For both sites meteorological and soil moisture time series data and information from field surveys and laboratory analysis were used to set up five soil profile models using Hydrus-1D. The model variants differed only in their following soil properties: soil layer depths, saturated hydraulic conductivity and water retention curve parameters. These properties were derived from: (i) calibration and validation ("presumably best" version), (ii) laboratory measurements of the sampled soil profile, (iii) estimations with European pedotransfer functions based on the measured easily available soil properties, (iv) estimations with European pedotransfer functions based on soil map information from the DOSoReMi.hu database and (v) the EU-SoilHydroGrids maps. We evaluated the model variants by the goodness-of-fit between the measured and simulated soil moisture time series (using NSME, RMSE, $\mathrm{R}^{2}$ ). The simulated water budgets were also compared for the five model variants.

The calibrated soil parameters lead to the best model performance at both locations (NSME was 0.49 and 0.75 for Fiad and Szalafo). The EU-SoilHydroGrids maps provided second best agreement, while contrary to expectations, the 
simulation based directly on the measured soil-hydrologic values were the weakest. Major differences occurred in the simulated water budgets, which can be attributed to the different environmental conditions at the two sites. Water budget results are mostly in line with the model efficiency indicators: on-site measured soil hydraulic parameters led to different results from the others. Based on the presented results we can assume that the widely used soil profile description and sampling practice might not properly suit the input needs of hydraulic simulations and can increase the uncertainty of modelling. The performance of soil hydraulic parameters derived with pedotransfer functions is promising, we will continue the more detailed analysis of 3D soil hydraulic property maps.

Keywords: soil moisture; soil hydraulic properties; Hydrus-1D; water budget;

\section{Tables and figures}

Table 1. Basic soil properties at Fiad and Szalafö. Columns from left to the right: (1) genetic horizon, (2) depth of the genetic horizon [cm], (3) organic matter content $[\mathrm{g} / 100 \mathrm{~g}]$, (4) calcium carbonate content $[\mathrm{g} / 100 \mathrm{~g}],(5) \mathrm{pH}\left(\mathrm{H}_{2} \mathrm{O}\right)$ [-], (6) upper limit of plasticity according to Arany $[\mathrm{g} / 100 \mathrm{~g}]$, (7) electrical conductivity $[\mathrm{mS} / \mathrm{cm}],(8)$ particle size distribution (9) sand, (10) silt, (11) loam [g/100g], (12) hydraulic conductivity [cm/day]

Table 2. Results of model variants, model efficiency coefficients. (1) model variant.

Figure 1. Precipitation, potential evapotranspiration (PET) and leaf area index (LAI) at Fiad and Szalafö measurement spots. (1) Precipitation [mm/day]. Legend: black columns: precipitation; black line: potential evapotranspiration; dashed grey line: LAI. X axis: date; left $\mathrm{Y}$ axis: PET [mm/day], LAI [-]; right $\mathrm{Y}$ axis: precipitation [mm/day].

Figure 2. Water retention curves (WRC): measured and estimated curves of the first horizon for (a) Fiad and (b) Szalafö. Measured WRCs of all horizons for (c) Fiad and (b) Szalafö. Legend: (a) and (b) soil-hydrologic databases used in the model variants; (c) and (b): genetic horizons. $\mathrm{X}$ axis: water content $\left[\mathrm{cm}^{3} / \mathrm{cm}^{3}\right]$, $\mathrm{Y}$ axis: $\mathrm{pF}$ value $[\log (\mathrm{cm})]$.

Figure 3. Measured and computed water content time series at Fiad for the REF model variant: 2016 (calibration, NSME $=0.64), 2017$ (validation, NSME $=0.22$ ). (1) Water content $\left[\mathrm{cm}^{3} / \mathrm{cm}^{3}\right]$ (2) Precipitation (3) Measures (4) Calculated. Legend: black columns: precipitation, black line: measured water content, grey line: computed water content. $X$ axis: date, left $Y$ axis: water content $\left[\mathrm{cm}^{3} / \mathrm{cm}^{3}\right]$, right $Y$ axis: precipitation [mm/day].

Figure 4. Measured and computed water content time series data at Szalafö for the REF model variant: 2013 (verification, NSME $=0.72), 2014$ (calibration, NSME = 0.80). (1) Water content $\left[\mathrm{cm}^{3} / \mathrm{cm}^{3}\right]$ (2) Precipitation (3) Measures (4) Calculated. Legend: black columns: precipitation, black line: measured water content, grey line: computed water content. $\mathrm{X}$ axis: date, left $\mathrm{Y}$ axis: water content $\left[\mathrm{cm}^{3} / \mathrm{cm}^{3}\right]$, right $\mathrm{Y}$ axis: precipitation [mm/day]. 
Figure 5. Two-year averaged water budget components of model variants: First column: (5) Runoff and (6) infiltration. Second column: (2) Changes in soil water storage, (3) evapotranspiration and (4) seepage into deeper soil layers. Interception and its evaporation is not presented in the figure. Legend: black: surface runoff, white: infiltration into soil, grey: change in water regime, dark grey: seepage into deeper zones, striped: evapotranspiration. $\mathrm{X}$ axis: model variants, Y axis: (1) water budget [mm/year].

Open Access nyilatkozat: A cikk a Creative Commons Attribution 4.0 International License (https://creativecommons.org/licenses/by/4.0) feltételei szerint publikált Open Access közlemény, melynek szellemében a cikk bármilyen médiumban szabadon felhasználható, megosztható és újraközölhető, feltéve, hogy az eredeti szerző és a közlés helye, illetve a CC License linkje és az esetlegesen végrehajtott módosítások feltüntetésre kerülnek. (SID_1) 